\title{
TRADUÇÃO FUNCIONALISTA E VARIAÇÃO LINGUÍSTICA: O USO DE SEQUÊNCIA DIDÁTICA NO ENSINO DE LÍNGUAS ${ }^{1}$
}

\author{
LA TRADUCCIÓN FUNCIONAL Y LA VARIACIÓN LINGÜÍSTICA: EL \\ USO DE SECUENCIA DIDÁCTICA EN LA ENSEÑANZA DE LENGUAS
}

\author{
FUNCTIONAL TRANSLATION AND LINGUISTIC VARIATION: THE \\ USE OF DIDACTIC SEQUENCE IN TEACHING LANGUAGES
}

\author{
Valdecy Oliveira PONTES ${ }^{2}$ \\ Livya Lea Oliveira PEREIRA ${ }^{3}$
}

RESUMO: No contexto da abordagem da variação linguística do Espanhol e do uso da Tradução Funcionalista em aulas de Língua Estrangeira, este artigo objetiva relatar os resultados da aplicação de uma Sequência Didática (SD), nos moldes da Escola de Genebra, a partir da tradução funcionalista de peças teatrais hispânicas para o ensino da variação linguística nas formas de tratamento pronominais no par linguístico EspanholPortuguês Brasileiro. A SD foi aplicada na disciplina "Introdução aos Estudos da Tradução em Língua Espanhola" ( $2^{\circ}$ semestre), ofertada pelo curso de licenciatura em Letras - Língua Espanhola e suas Literaturas, da Universidade Federal do Ceará. Baseamo-nos em fundamentos teóricos da Tradução Funcionalista (NORD, 1994, 1996, 2009, 2012), Tradução e Sociolinguística (BOLAÑOS-CUELLAR, 2000; MAYORAL, 1998), elaboração de SD (DOLZ; NOVERRAZ; SCHNEUWLY, 2004; CRISTÓVÃO, 2010; BARROS, 2012) e pesquisas sobre a variação nas formas de tratamento do Espanhol e Português (FONTANELLA DE WEINBER, 1999; SCHERRE et al, 2015).

PALAVRAS-CHAVE: Tradução Funcionalista. Sequências didáticas. Variação linguística. Formas de tratamento.

RESUMEN: En el contexto de abordaje de la variación lingüística del Español y del uso de la Traducción Funcional en las clases de Lengua Extranjera, este artículo objetiva relatar los resultados de la aplicación de una Secuncia Didáctica (SD), teniendo en cuenta el modelo propuesto por la Escuela de Ginebra, a partir de la

\footnotetext{
${ }^{1}$ Este artigo é um recorte da dissertação de mestrado “A tradução de textos teatrais como recurso didático para o ensino da variação linguística no uso das formas de tratamento em espanhol a aprendizes brasileiros", defendida por Livya Lea de Oliveira Pereira junto ao Programa de Pós-graduação em Estudos da Tradução da Universidade Federal do Ceará, em 2016, sob orientação do Prof. Dr. Valdecy de Oliveira Pontes.

${ }^{2}$ Universidade Federal do Ceará - (UFC), Fortaleza - Ceará - Brasil. Professor Adjunto. Atua na graduação em Letras-Espanhol e nos Programas de Pós-graduação em Linguística (PPGL) e em Estudos da Tradução (POET). Doutor em Linguística Aplicada, Universidade Federal do Ceará - (UFC). E-mail: valdecy.pontes@ufc.br

${ }^{3}$ Universidade Federal de Santa Catarina - (UFSC), Florianópolis - Santa Catarina - Brasil. Doutoranda no Programa de Pós-graduação em Linguística. E-mail: pluralizado@ hotmail.com
} 
traducción funcional de obras teatrales hispánicas para la enseñanza de la variación lingüística en las formas de tratamiento pronominales en las lenguas Española y Portugués Brasileño. La SD ha sido aplicada en la asignatura "Introducción a los Estudios de Traducción en Lengua Española" (2 ${ }^{\circ}$ semestre), ofrecida por el curso de Letras - Lengua Española y sus Literaturas, de la Universidad Federal de Ceará. Nos basamos en los aportes teóricos de la Traducción Funcional (NORD, 1994, 1996, 2009, 2012), Traducción y Sociolingüística (BOLAÑOS-CUELLAR, 2000; MAYORAL, 1998), elaboración de una SD (DOLZ; NOVERRAZ; SCHNEUWLY, 2004; CRISTÓVÃO, 2010; BARROS, 2012) e investigaciones sobre la variación en la formas de tratamiento en Español y Portugués Brasileño (FONTANELLA DE WEINBER, 1999; SCHERRE et al, 2015).

PALABRAS CLAVE: Traducción funcional. Secuencias didácticas. Variación lingüística. Formas de tratamiento.

ABSTRACT: In the context of the approach of the linguistic variation of Spanish and the use of Functionalist Translation in Foreign Language classes, this article aims to report the results of the application of a Didactic Sequence (SD), in the style of the Geneva School, Hispanic plays for the teaching of linguistic variation in the pronominal treatment forms of the Spanish-Portuguese Brazilian language pair. SD was applied in the subject "Introduction to Translation Studies in Spanish Language" (2nd semester), offered by the course in Letters - Spanish Language and its Literatures, of the Federal University of Ceará. This article was based on the theoretical foundations of Functionalist Translation (NORD, 1994, 1996, 2009, 2012), Translation and Sociolinguistics (BOLAÑOS-CUELLAR, 2000; MAYORAL, 1998), elaboration of SD (DOLZ; NOVERRAZ; SCHNEUWLY, 2004; CRISTÓVÃO, 2010; BARROS, 2012) and research on the variation in the forms of treatment of Spanish and Portuguese (FONTANELLA DE WEINBER, 1999; SCHERRE et al, 2015).

KEYWORDS: Functionalist translation. Didactic sequences. Linguistic variation. Forms of treatment.

\section{INTRODUÇÃO}

Nas diversas abordagens de ensino-aprendizagem de Línguas Estrangeiras, o uso da tradução se deu, em maior ou menor medida, desde a tradução como técnica de ensino até o seu uso como estratégia de aprendizagem ou recurso didático, embora, muitas vezes, tal uso fosse objeto de críticas permeadas por estereótipos negativos, por exemplo, ao considerar a tradução como uma atividade artificial e não comunicativa. No entanto, atualmente, muitas pesquisas já mostraram que o uso da tradução no Ensino de Língua Estrangeira (LE) pode trazer resultados positivos, considerando-se: (i) o 
contexto de ensino; (ii) os objetivos de ensino-aprendizagem; (iii) o nível dos alunos; (iv) os avanços teóricos dos Estudos da Tradução; (v) as contribuições da Didática da Tradução para o Ensino de LE. São exemplos, no contexto nacional, as pesquisas de Melo (2012), Barrientos (2014), Demétrio (2014), entre outras. Portanto, a questão não é mais se é possível ou não usar a tradução no Ensino de Línguas Estrangeiras, mas como aplicá-la e qual a real contribuição da atividade tradutória, em diferentes contextos de aprendizagem. Nesse âmbito, pesquisas aplicadas/experimentais sobre o uso da tradução, em suas diferentes modalidades, podem contribuir tanto para o campo de estudo sobre Tradução e Ensino de Línguas quanto para a prática docente, principalmente, no contexto do pós-método (KUMARAVADIVELU, 2001).

Assim, é no contexto de pós-método e de interdisciplinaridade dos Estudos da Tradução que nossa proposta se insere, ao relatar a experiência de aplicação de uma sequência didática (SD) a partir da tradução funcional de fragmentos de peças teatrais hispânicas para o ensino-aprendizagem da variação linguística, das formas de tratamento pronominais das variedades do Espanhol (tú, vos, usted, vosotros, ustedes) e do Português Brasileiro (PB). Para tanto, este artigo está organizado nas seguintes seções: 1. Tradução Funcionalista, Variação Linguística e Sequências Didáticas; 2. Metodologia; 3. Análise dos Resultados.

\section{Tradução funcionalista, variação linguística e sequências didáticas}

Na proposta de SD desenvolvida, vislumbramos conexões entre a perspectiva da Tradução Funcionalista, Variação Linguística e Sequências Didáticas. No que diz respeito à Tradução Funcionalista, essa corrente é originada na década de 70, sob influência do Funcionalismo linguístico, Pragmática, Sociologia e Antropologia (REISS; VERMEER, 1996, p. 104). Essa perspectiva de tradução busca se desprender do puramente linguístico, para incluir aspectos contextuais, culturais e interacionais, considerando, dessa forma, tanto a situação comunicativa do texto-base (TB) quanto a do texto-meta (TM). Nesse viés, Nord (2012) assevera que a tradução é uma interação comunicativa intercultural mediada, entre emissor e receptor que pertencem a culturas distintas e, por isso, necessitam da mediação intercultural de um tradutor/intérprete. 
Para Nord (2012, p. 16), o texto tem papel central para o ato tradutório, pois consiste em uma interação comunicativa que se efetua através de uma combinação de elementos verbais e não verbais. Logo, todo texto se situa dentro de um sistema de determinados elementos interdependentes (fatores extratextuais) que configuram a função textual. Sobre essa questão, Nord (1994, p. 101) explica que um texto não possui uma função comunicativa inerente, mas esta lhe é atribuída a partir da sua recepção por alguém, em uma situação específica, ativando suas experiências receptivas e convenções de funcionamento de certos tipos de texto. Assim, na concepção da autora, o significado de um texto é constituído pela interdependência entre forma e conteúdo dos elementos textuais e a sua função ou funções comunicativas. Nessa questão, a função ou as funções textuais influenciarão as formas de tradução.

Na visão de Nord (2012), a identificação do objetivo e função do TM é de suma importância para determinar os tipos e as formas de tradução. Nesse sentido, a autora afirma que as descrições unilaterais ou contrastivas dos gêneros textuais auxiliam o ato tradutório, uma vez que se as informações extratextuais são a base para identificar a função do texto, a tipologia textual permite que o tradutor antecipe algumas características intratextuais e, por sua vez, se as características extratextuais de um texto são escassas, uma tipologia textual poderá servir para que o tradutor interprete determinados elementos intratextuais em relação a sua funcionalidade em uma determinada cultura.

Por outro lado, conforme a autora, na perspectiva funcional, classificar um texto como um gênero determinado não poderá consistir em uma "receita" para a sua tradução. Por conta disso, ela propõe uma análise exaustiva que considere os fatores intra e extratextuais tanto do TB quanto do TM.

Com base nesse procedimento, a autora elabora um modelo de análise prétradutória a partir da inter-relação dos aspectos extra e intratextuais, o qual expomos no Quadro 1. A tradução, assim como a análise pré-tradutória, é guiada pelo encargo de tradução (situação comunicativa) o qual pode ser elaborado com fins didáticos, seguindo os princípios da transparência, autenticidade e comunicabilidade. Ademais, a autora menciona que esse modelo pode ser aplicado ao Ensino de Línguas, desde que não se limite à análise linguística do TB ou às intenções do autor e sua verbalização. 
Quadro 1: Análise pré-tradutória proposta por Nord (2012)

\begin{tabular}{|c|c|c|c|}
\hline & Perfil do texto base & Transferência & Perfil do texto meta \\
\hline \multicolumn{4}{|c|}{ Aspectos extratextuais } \\
\hline \multicolumn{4}{|l|}{ Emissor } \\
\hline \multicolumn{4}{|l|}{ Intenção } \\
\hline \multicolumn{4}{|l|}{ Receptor } \\
\hline \multirow{2}{*}{\multicolumn{4}{|c|}{$\begin{array}{l}\text { Meio } \\
\text { Lugar }\end{array}$}} \\
\hline & & & \\
\hline \multicolumn{4}{|l|}{ Tempo } \\
\hline \multicolumn{4}{|l|}{ Motivo } \\
\hline \multicolumn{4}{|l|}{ Função } \\
\hline \multicolumn{4}{|c|}{ Aspectos intratextuais } \\
\hline \multirow{2}{*}{\multicolumn{4}{|c|}{ Tema }} \\
\hline \multirow{2}{*}{\multicolumn{4}{|c|}{$\begin{array}{l}\text { Conteúdo } \\
\text { Pressuposicões }\end{array}$}} \\
\hline & & & \\
\hline \multicolumn{4}{|l|}{ Composição } \\
\hline \multicolumn{4}{|l|}{ Elementos não verbais } \\
\hline \multicolumn{4}{|l|}{ Léxico } \\
\hline \multicolumn{4}{|l|}{ Sintaxe } \\
\hline \multicolumn{4}{|l|}{ Suprassegmentais } \\
\hline & Efeito & unicativo & \\
\hline Efeito & & & \\
\hline
\end{tabular}

Fonte: Adaptado de Nord (2012, p. 155).

Se compararmos a perspectiva teórica da Tradução Funcionalista com a da Sociolinguística Variacionista, podemos pensar em uma aproximação interdisciplinar. Pois, ambas objetivam entender a função comunicativa de certo enunciado ou forma linguística utilizada, num determinado contexto, por um falante específico. Nesse sentido, Paiva e Duarte (2006, p. 147) destacam que: “A associação entre pressupostos variacionistas e pressupostos funcionalistas se apoia essencialmente num ponto de partida comum: o de que a língua só pode ser entendida nos seus variados contextos de uso". Dessa maneira, a análise do fenômeno de variação e mudança linguística pode contribuir à prática tradutória funcional, visto que o estudo da variação linguística também identifica condicionamentos linguísticos e extralinguísticos. Assim, as pesquisas sociolinguísticas podem possibilitar ao tradutor o entendimento e a escolha adequada entre duas ou mais variantes de uma língua meta para um determinado encargo tradutório ou, ainda, podem auxiliá-lo na compreensão do uso de uma determinada variante da língua-base para traduzi-la à língua-meta.

Nord (1994) expõe que a tradução, na perspectiva funcional, tem que se adaptar às normas e convenções culturais de uma dada cultura e, nessa questão, os conhecimentos sociolinguísticos também podem contribuir à tradução, ao 
desenvolverem estudos que descrevem as normas sociais de uma dada língua. No âmbito dos Estudos da Tradução, alguns autores destacam a aproximação entre a Tradução e a Sociolinguística. Bolaños-Cuéllar (2000, p.158), a título de ilustração, defende, no marco da interdisciplinaridade dos Estudos da Tradução, que a Sociolinguística pode contribuir à compreensão, análise e possíveis soluções de problemas de tradução, no tocante à preservação das formas de tratamento de uma língua a outra, conservação de socioletos, gírias, registros etc., durante o processo de tradução e em seu produto textual.

Na visão de Mayoral (1998), muitos estudos sobre tradução trataram do problema da variação linguística, com ênfase na tradução de dialetos. Entretanto, quando se trata da tradução de variantes concretas, ora falam de forma insuficiente ora tecem simples considerações sobre o estilo. $\mathrm{O}$ autor menciona que, com os conceitos de skopos e encargo de tradução propostos pela Tradução Funcionalista, rompe-se com o conceito de equivalência linguística entre o TB e o TM, em prol de uma adequação do TM ao seu encargo de tradução, fato que norteará a forma com que o tradutor lidará com a variação linguística no TM. Pois, também estará submetida a seu encargo de tradução e eficácia comunicativa. Nesse sentido, nas palavras do autor: "O tradutor traduz textos (mensagens) específicos com marcadores sociolinguísticos e esta tradução se ajusta a um encargo e às exigências gerais da eficácia da comunicação" (MAYORAL, 1998, p. 140, tradução nossa) ${ }^{4}$.

Notamos que, na Tradução Funcional, o texto tem papel central e não existe texto sem variedade linguística, uma vez que as línguas são dotadas de heterogeneidade sistemática. Para além disso, comunicamo-nos através de textos (orais, escritos, visuais), portanto, quando falamos em texto, referimo-nos a gêneros textuais, os quais podem ser compreendidos como: "uma noção propositalmente vaga para referir os textos materializados que encontramos em nossa vida diária e que apresentam características sociocomunicativas definidas por conteúdos, propriedades funcionais, estilo e composição característica" (MARCUSCHI, 2010, p. 23).

Em relação ao ensino-aprendizagem dos gêneros textuais, Dolz e Schneuwly (1996) entendem o gênero como um megainstrumento para agir em situações de

${ }^{4}$ Citação original: "El traductor traduce textos (mensajes) específicos con marcadores sociolingüísticos y esta traducción se ajusta a un encargo específico y a las exigencias generales de la eficacia de la comunicación." (MAYORAL, 1998, p. 140) 
linguagem e propõem que tais gêneros sejam introduzidos em nossas experiências e consciência mediante três fatores: práticas de linguagem, capacidades de linguagem e as estratégias de aprendizagem. Na sequência, apresentamos a descrição de tais capacidades de linguagem, a partir de Stutz e Cristóvão (2011):

Figura 1: Descrição das capacidades de linguagem por Stutz e Cristóvão (2011)
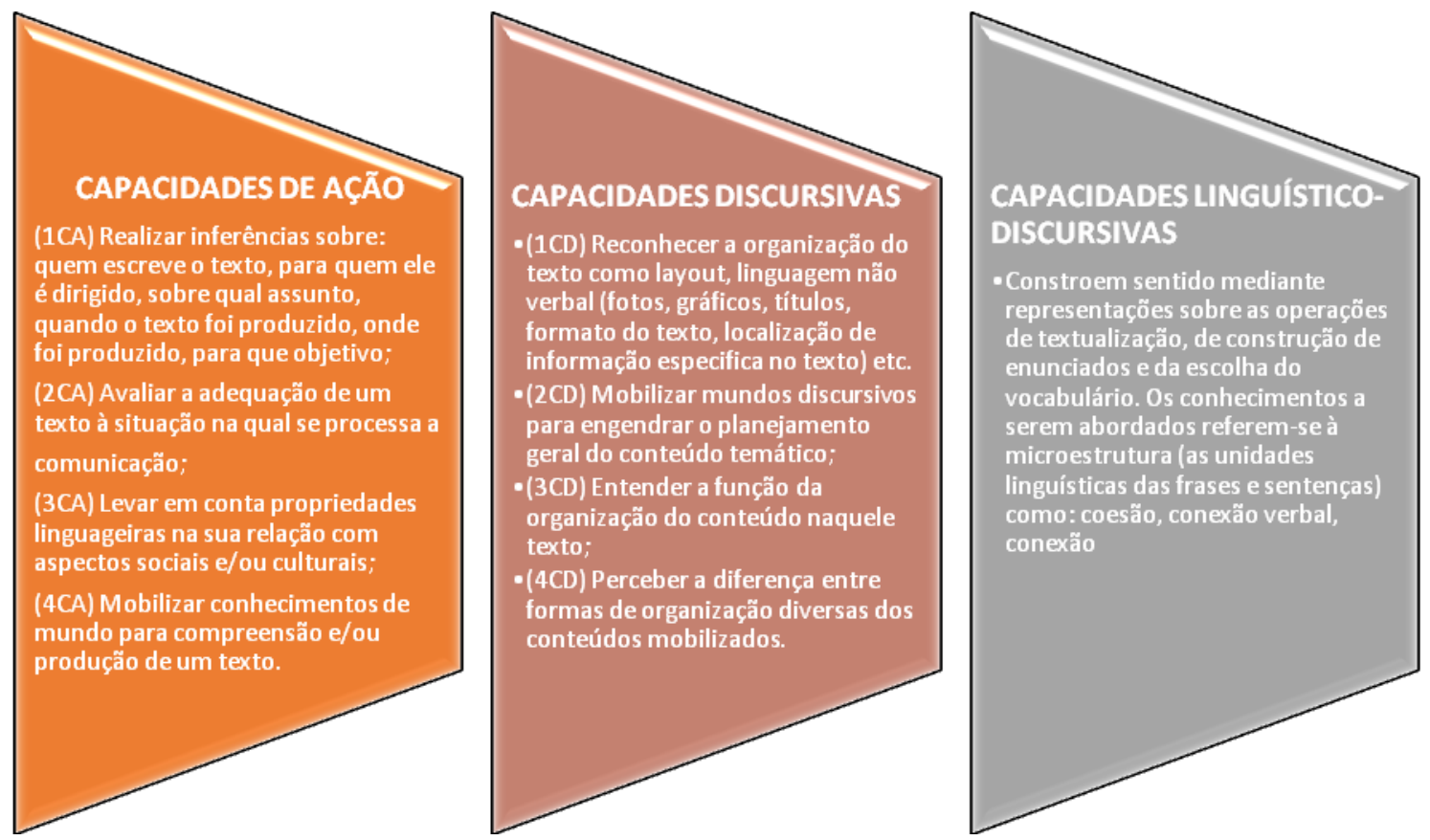

Fonte: Adaptado de Stutz e Cristóvão (2011).

Considerando essas capacidades para o ensino de gêneros, Dolz, Noverraz e Schneuwly (2004) propõem o seguinte procedimento de SD:

Figura 2: Esquema da SD proposto por Dolz, Noverraz e Schneuwly (2004)

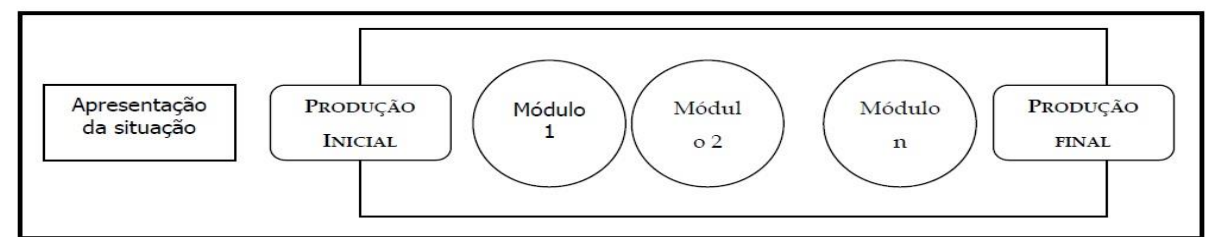

Esquema da sequiência didática

Fonte: Dolz, Noverraz e Schneuwly (2004, p. 97)

Uma SD, conforme Dolz, Noverraz e Schneuwly (2004, p. 96), é: “[...] um conjunto de atividades escolares organizadas, de maneira sistemática, em torno de um 
gênero textual oral ou escrito." Para os autores, quando nos comunicamos, adaptamonos à situação comunicativa e, quando interagimos em situações parecidas, escrevemos/falamos textos com características semelhantes, os quais são considerados gêneros textuais. A partir desse procedimento, vislumbramos a possibilidade de uma SD a partir da tradução funcionalista, uma vez que as capacidades de linguagem são contempladas no modelo de análise pré-tradutória (Figura 2) e a tradução contempla os elementos de textualidade, tais como: intencionalidade, aceitabilidade, intertextualidade, informatividade, coerência, coesão, adequação e correção gramatical (DEMÉTRIO, 2014).

Figura 3: As capacidades de linguagem dentro da análise pré-tradutória de Nord (2012)

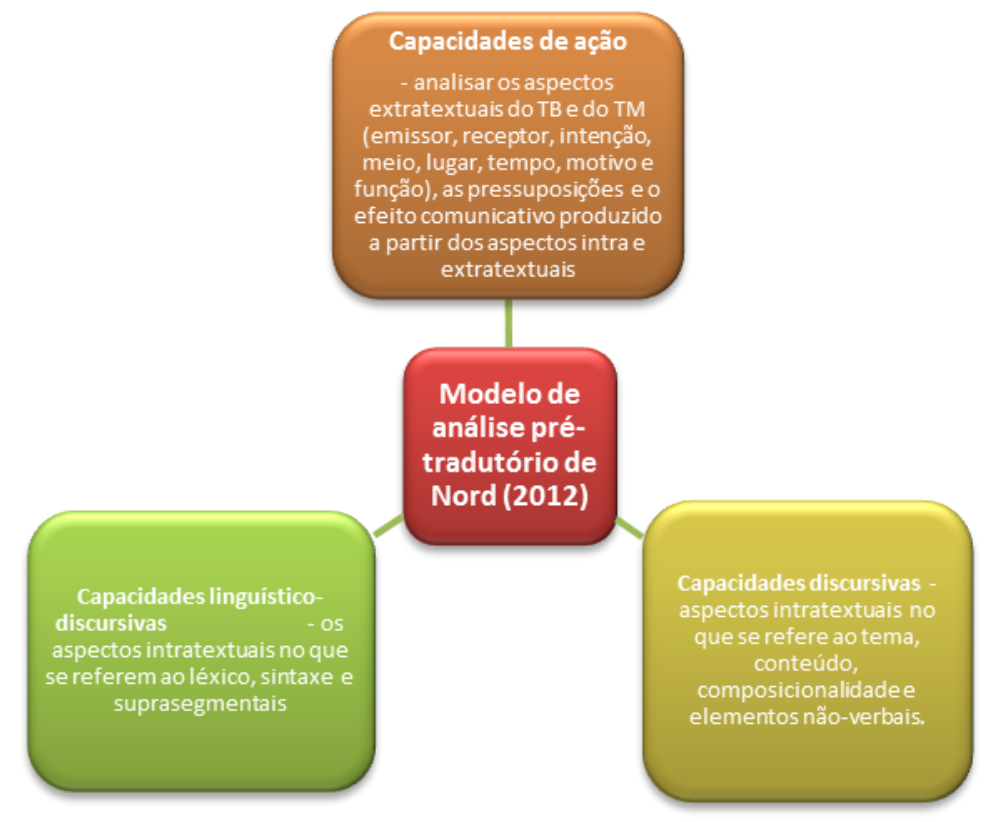

Fonte: Autoria própria.

Conforme o discorrido até agora, verifica-se que uma SD com o uso da Tradução Funcionalista pode contemplar todos os requisitos para um trabalho colaborativo que uma SD exige entre professor e alunos, os quais são especificados por Cristóvão (2009), da seguinte forma:

Para garantir um trabalho de colaboração entre professor e alunos, a sequência didática deve contemplar: a) uma esfera de atividade em que o gênero circule; b) a definição de uma situação de comunicação na qual a produção se insere; c) conteúdos apropriados; d) a disponibilização de textos sociais (de circulação real) como referências para os alunos; e) uma organização geral de ensino que vá 
ao encontro das transformações desejadas; f) atividades que contribuam para que os objetivos sejam alcançados; g) propostas de percursos e situações que levem o aluno a atingir os objetivos desejados. (CRISTÓVÃO, 2009, p. 309)

Dessa forma, mediante as relações pontuadas entre o procedimento de uma SD e o processo tradutório, na perspectiva da Tradução Funcionalista, reiteramos a possibilidade de empreender uma SD, a partir da tradução funcional de gêneros textuais. Tal prática, no contexto de ensino específico desta pesquisa, objetiva, ainda, contemplar as capacidades exigidas ao aluno de graduação em Letras Língua Espanhola e suas Literaturas, da Universidade Federal do Ceará, no que se refere ao conhecimento e respeito às diferentes variedades linguísticas, mediação em contextos interculturais e uso de conhecimentos da Língua Espanhola na prática tradutória. Embora o objetivo geral desta pesquisa centre-se na análise das contribuições da atividade tradutória, em forma de SD, para o ensino da variação linguística, no tocante ao uso das formas de tratamento do Espanhol e do Português Brasileiro em nível inicial de aprendizagem. A seguir, discorremos brevemente sobre o percurso metodológico empreendido para a aplicação da SD.

\section{Metodologia}

A partir do referencial teórico exposto, elaboramos uma SD que foi aplicada na disciplina "Introdução aos Estudos da Tradução em Língua Espanhola" (2ºmestre), ofertada de forma optativa, pela coordenação do Curso em Letras Língua Espanhola e suas Literaturas, da Universidade Federal do Ceará (UFC) - Centro de Humanidades I, Fortaleza - CE. A disciplina tinha a carga horária total de 32 horas, resultando em um encontro semanal, durante 16 semanas. Vale destacar que a escolha por alunos(as) matriculados(as) nessa disciplina resultou da aproximação temática dessa com os objetivos da pesquisa. Ademais, essa disciplina consistiu no Estágio de Docência da própria pesquisadora, portanto todo o procedimento da SD foi guiado por ela, durante a primeira metade do semestre, isto é, 8 semanas (16 h/a).

Por ser uma optativa, estudantes de outros semestres puderam participar da disciplina, mas para participar da pesquisa somente foram considerados: 1. Aprendizes brasileiros de Língua Espanhola sem parentes de origem hispânica em primeiro grau; 2 . 
Estudantes em nível A2 (segundo semestre do curso de graduação); 3. Estudantes de ambos os sexos, com o Português Brasileiro como LM; 4. Estudantes regularmente matriculados na disciplina; 5. Estudantes que concordaram, de livre e espontânea vontade, em participar da pesquisa, assinando o Termo de Consentimento Livre e Esclarecido para os participantes da pesquisa, exigido pelo Comitê de Ética.

Para a SD, a turma foi dividida em 8 grupos de 4 ou 5 estudantes, visando a uma escrita colaborativa, com o foco no processo e não no produto. Selecionamos cinco peças teatrais hispânicas como TB dos grupos, a partir dos seguintes critérios: a) peças teatrais de diferentes países hispânicos, apresentando casos de variação linguística nas formas de tratamento, de acordo com a divisão de Fontanella de Weinberg (1999) ${ }^{5}$; b) período histórico de publicação da obra (segunda metade do século XIX ou primeira metade do século XX); c) gênero comédia; d) extensão (50 a 60 páginas); e) disponibilidade na internet. Além disso, os fragmentos de cada peça foram selecionados por meio da frequência das formas de tratamento pronominais e da relevância do fragmento para o enredo da peça teatral. A seguir, expomos as peças escolhidas:

Quadro 2: Peças teatrais selecionadas para a SD

\begin{tabular}{|c|c|c|c|c|c|}
\hline Obra/ & El nido ajeno/ & El héroe galopante/ & La pobre gente/ & Pueblecito/ & Los Mirasoles/ \\
Autor & Jacinto & Nemesio C. & Florencio & Armando & Julio Sánchez \\
(Ano) & Benavente & Canales & Sánchez & Mook & Gardel \\
& $(1894)$ & $(1923)$ & $(1904)$ & $(1918)$ & $(1911)$ \\
\hline
\end{tabular}

Fonte: Autoria própria.

O encargo de tradução didático seguiu as diretrizes propostas por Nord (1996). Desse modo, elaboramos um blog intitulado "Traduciendo el Teatro Hispánico" (http://traduccionyteatrohispanico.blogspot.com.br/), a fim de contemplar o princípio da comunicabilidade e, ainda, repassou as seguintes informações aos grupos:

\footnotetext{
${ }^{5}$ Fontanella de Weinberg (1999) propõe a divisão dos sistemas de tratamento pronominais da Língua Espanhola, a partir de quatro sistemas, no qual o Sistema III é subdividido em III.a e III.b. Baseando-nos nesta divisão, apresentada na seção 3.2.1, selecionamos 5 países para a escolha das peças teatrais, um para cada sistema proposto por esta divisão, a saber: Espanha (Sistema Pronominal I); Porto Rico (Sistema Pronominal II); Uruguai (Sistema Pronominal III.a); Chile (Sistema Pronominal III.b) e Argentina (Sistema Pronominal IV)
} 
Quadro 3: Definição do encargo de tradução didático para a SD

\begin{tabular}{|c|c|}
\hline $\begin{array}{l}\text { 1. A função ou funções comunicativas do } \\
\text { TM }\end{array}$ & $\begin{array}{l}\text { Adaptar obras teatrais hispânicas de comédia para o } \\
\text { entretenimento do público brasileiro adulto atual. }\end{array}$ \\
\hline 2. Os destinatários do TM & Brasileiros(as) de diferentes regiões do país. \\
\hline $\begin{array}{l}\text { 3. As condições temporais e locais } \\
\text { previstas para a recepção do } \mathrm{TM}\end{array}$ & Século XXI, ano 2016; Brasil. \\
\hline $\begin{array}{l}\text { 4. O meio pelo qual será transmitido o } \\
\text { TM }\end{array}$ & Ambiente Virtual: blog. \\
\hline 5. O motivo pelo qual se produz o texto & $\begin{array}{l}\text { Divulgar antigas obras teatrais hispânicas para o público } \\
\text { brasileiro, na internet. }\end{array}$ \\
\hline
\end{tabular}

Fonte: Autoria própria.

A partir desse encargo tradutório, cada grupo selecionou um fragmento de peça teatral para traduzir, além de eleger uma das cidades brasileiras, sugeridas pela pesquisadora, como seu público-meta. As cidades sugeridas foram escolhidas a partir da divisão dos subsistemas de tratamento pronominais, proposta por Scherre et. al. (2015). Assim, elencamos: Fortaleza (Região Nordeste - Subsistema "tu/você com concordância média"); Belém do Pará (Região Norte - Subsistema "mais tu com concordância alta"); São Paulo (Região Sudeste - Subsistema "só você"); Brasília (Região Centro-Oeste - Subsistema "você/tu sem concordância") e Florianópolis (Região Sul - Subsistema "mais tu com concordância alta"). A seguir, expomos o projeto inicial da SD:

Figura 4: Etapas do projeto inicial da SD com a tradução do gênero peça teatral

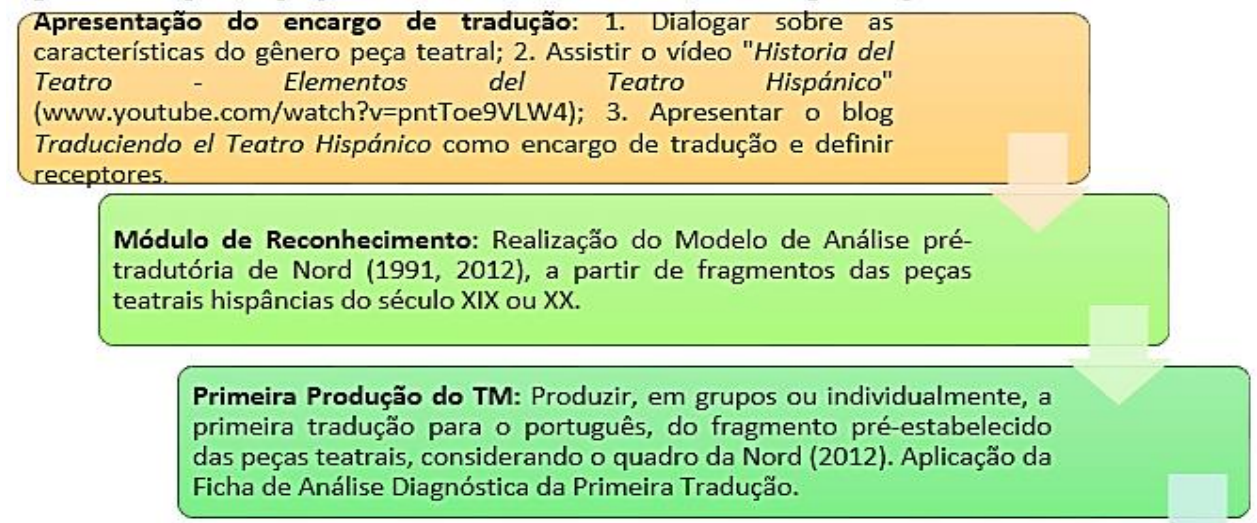

Primeira Produção do TM: Produzir, em grupos ou individualmente, a tradução para o português, do fragmento pré-estabelecido Ficha de Análise Diagnóstica da Primeira Tradução.

Módulos e lista de constatações: a partir da Análise Diagnóstica da Primeira Tradução, cria-se os módulos de acordo com as reais dificuldades dos aprendizes. Após aplicação dos módulos, integrando as capacidades de linguagem, realiza-se uma lista de constatações dos conhecimentos integralizados.

Produção final do TM, revisão final e circulação social: 1. Produzir a última versão da tradução para o português, de um fragmentode peça teatral; 2. Socializar as traduções com os demais grupos; 3 . Revisar e publicar as traduções no Blog Traduciendo el Teatro Hispánico.

Fonte: Autoria própria. 
É importante esclarecer que, ao elaborar a SD com a tradução do gênero peça teatral de comédia, realizamos o Modelo Didático do Gênero, com base em Cristóvão (2010) e Barros (2012), o qual serviu como base para a elaboração da Grade de Análise Diagnóstica da Primeira Tradução, composição dos módulos e da lista de constatações. Entretanto, devido aos limites de extensão deste artigo, não expomos tais elementos.

Em relação à análise pré-tradutória, essa consistiu em um módulo de reconhecimento do gênero, antes da primeira tradução, através da qual constatamos dificuldades relacionadas à identificação do receptor, lugar, função, conteúdo, composição e aspectos suprassegmentais, no TB e TM. Dentre esses aspectos, na Primeira Tradução, também, observamos dificuldades no que se refere à adaptação do TM ao receptor e lugar de recepção (capacidades de ação), à planificação e organização do gênero (capacidades discursivas) e à adaptação do TM à gramática, vocabulário e ortografia, falha na adequação da tradução das formas de tratamento pronominais de acordo com a origem de seu público-meta, além da generalização das relações sociais entre as personagens, por meio do uso da forma "você" (capacidades linguísticodiscursivas).

A partir dessas dificuldades, propusemos oito módulos, os quais buscaram contemplar todas as capacidades de linguagem, principalmente, as linguísticodiscursivas, uma vez que o objetivo da SD visava à abordagem da variação linguística nas formas de tratamento pronominais. Após a realização dos módulos, realizamos uma ficha de revisão textual como forma de lista de constatações e os grupos reescreveram os TM para a publicação no blog. Dessa forma, na figura 4, ilustramos a SD final aplicada: 
Figura 5: Versão Final da SD

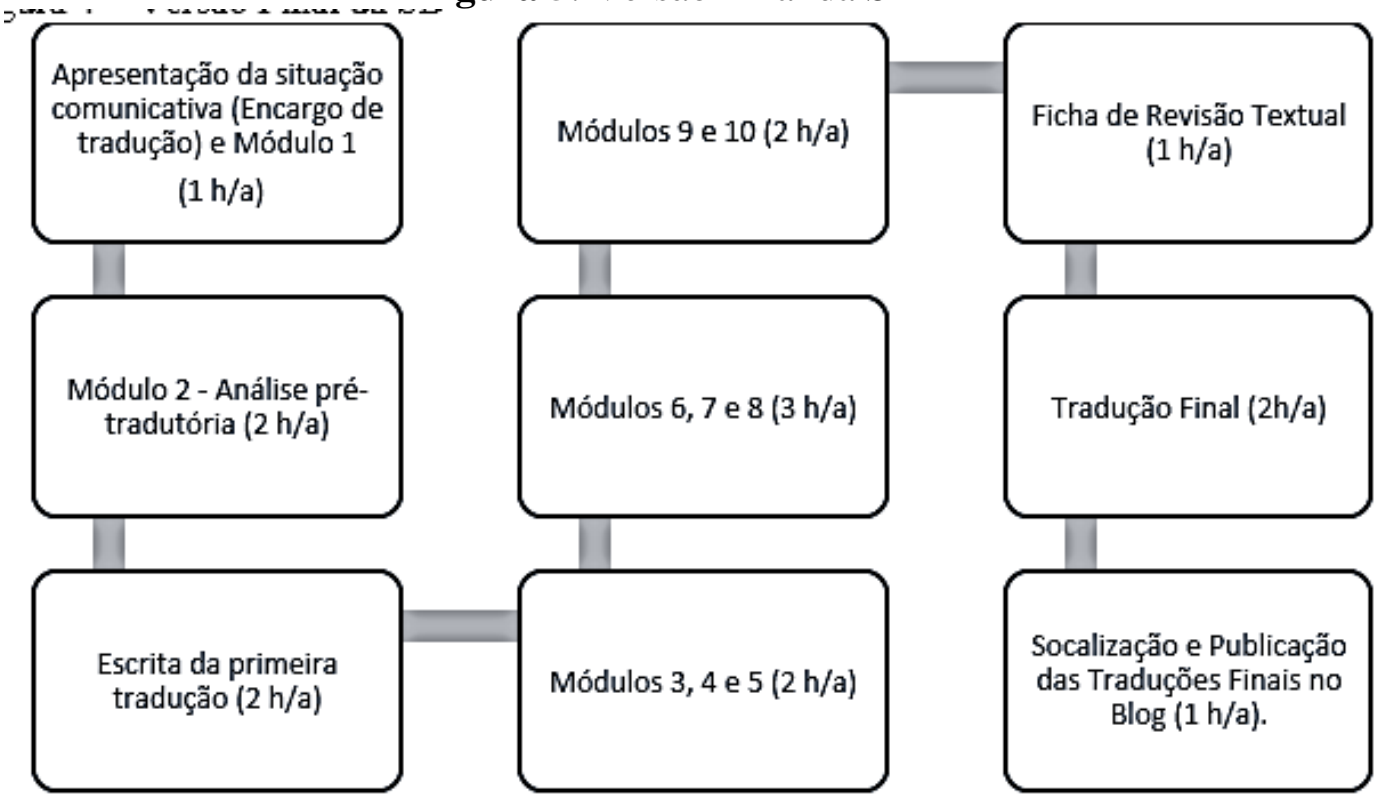

Fonte: Autoria própria.

Apresentamos, na próxima seção, apenas o resultado do contraste entre as produções da SD de dois dos grupos analisados, os quais denominamos G-I e G-II. O GI teve como TB um fragmento da peça espanhola El Nido Ajeno (BENAVENTES, 1894) e o seu público-meta era a cidade de São Paulo, do séc. XXI. Por sua vez, o G-II teve como TB um fragmento da peça porto-riquenha El héroe galopante (CANALES, 1923) e o seu público-meta era a cidade de Florianópolis.

\section{Análise dos resultados}

Nesta seção, apresentamos os resultados oriundos da aplicação da sequência didática, nos grupos I e II. Para isso, comparamos a primeira e a última produção de cada grupo, considerando o desenvolvimento das capacidades de ação, linguísticodiscursivas e linguísticas.

No que tange à última produção do G-I, notamos que o grupo realizou algumas modificações com o intuito de adaptar o seu texto ao encargo de tradução, principalmente, no que se refere à linguagem, ao lugar e ao tempo do receptor, isto é, ao público da cidade de São Paulo, do séc. XXI (capacidades de ação). Por exemplo, vimos que, na primeira tradução, o grupo usou expressões próximas ao Texto-Base (TB), no Texto-Meta (TM), tais como "Julepe", "pousei como uma mariposa" e "um tio", as 
quais se distanciavam do receptor estipulado no encargo de tradução. No entanto, como observamos, no quadro a seguir, o grupo reescreveu o trecho em que aparece "Jogava-se ao Julepe", utilizando a frase "a gente jogava cartas", igualmente, a expressão "pousei como uma mariposa" foi substituída pelo verbo "curtir".

Quadro 4: Trecho comparativo entre as traduções do G-I (capacidades de ação)

\begin{tabular}{|c|c|}
\hline $\begin{array}{l}\text { Texto } \\
\text { Base }\end{array}$ & $\begin{array}{l}\text { MARÍA.- A todo se acostumbra una, y yo no estoy acostumbrada a divertirme mucho. Bien lo } \\
\text { sabes tú; en mi casa pasaba lo mismo. } \\
\text { EMILIA.- En tu casa siquiera, había tertulia los sábados. Se jugaba al julepe, se tomaba } \\
\text { chocolate, iban nuestros novios. } \\
\text { MARÍA.- Nuestros maridos hoy. } \\
\text { EMILIA.- Y el tuyo fue el primero y el único. ¡Has sido siempre tan formal! Yo mariposee un } \\
\text { poco, con aquel sevillano, ¿te acuerdas? Si me caso con él me luzco! Qué vida dio a su pobre } \\
\text { mujer! Nosotras no podemos quejarnos. Tuximos buen acierte. }\end{array}$ \\
\hline $\begin{array}{l}\text { Primeira } \\
\text { tradução }\end{array}$ & $\begin{array}{l}\text { Maria: A tudo se acostuma, e eu não estou acostumada a me divertir muito. Bem o sabes você; Na } \\
\text { minha casa acontecia o mesmo. } \\
\text { Emília: Na tua casa nem sequer tinha uma reunião entre amigos aos sábados, Jogava-se ao Julepe, } \\
\text { tomava-se chocolate, iam nossos namorados. } \\
\text { Maria: Nossos maridos agora. } \\
\text { Emilia: e teu foi o primeiro o único. Você sempre foi tão formal! Eu pousei como uma } \\
\text { mariposa um pouco com aquele sevilhano. Se lembra? Se tivesse me casado com ele me } \\
\text { exibiria. Que vida deu a sua pobre mulher! Nós não podemos reclamar. Tivemos sucesso. }\end{array}$ \\
\hline $\begin{array}{l}\text { Tradução } \\
\text { Final }\end{array}$ & $\begin{array}{l}\text { Maria: Acostuma e eu não sou baladeira. Você sabe. Na minha casa todo mundo é assim. } \\
\text { Emília: Na tua casa nem te encontro aos sábados, a gente jogava cartas, bebia chocolate, nossos } \\
\text { namorados também iam. } \\
\text { Maria: Nossos maridos agora. } \\
\text { Emília: E o teu foi o primeiro e o único. Você sempre foi tão formalt Eu curti um pouco com } \\
\text { aquele sevilhano. Se lembra? Se tivesse me casado com ele me ferrava. Fudeu a sua pobre mulher! } \\
\text { Não podemos reclamar. Nos demos bem. }\end{array}$ \\
\hline
\end{tabular}

Fonte: Autoria própria

Nesse quadro, ainda, podemos verificar que o grupo realizou outras adaptações, as quais destacamos pelo sublinhado, tais como o uso das expressões "baladeira", "me ferrava" e "Fudeu", que também se aproximam da linguagem do receptor-meta do TM, no séc. XXI. Ademais, averiguamos que o grupo respeitou as características do gênero textual peça de teatro no que se refere à planificação e organização das partes (tipo de discurso, organização sequencial, conexão e coesão), em ambas as traduções. O TM apresenta a divisão entre as cenas, a entrada de personagens antes do início dos diálogos, além da presença das rubricas (didascálias) descritivas entre parênteses, conforme constatamos na Figura 5, na sequência. 
Figura 6: Trecho da Tradução Final do G-I

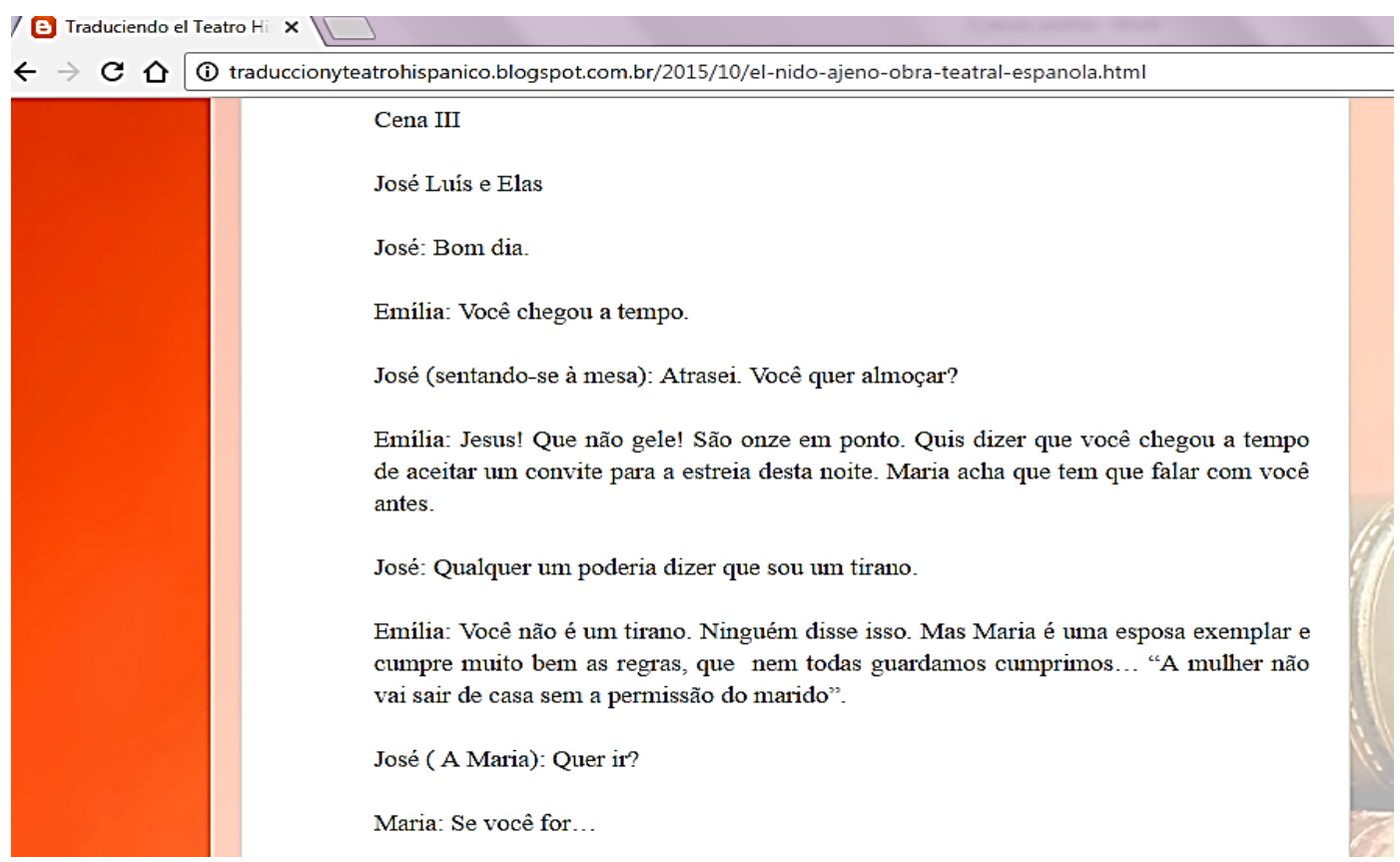

Fonte: Blog Traduciendo el Teatro Hispánico.

Quanto às capacidades linguístico-discursivas, na Primeira Tradução, encontramos trechos com inadequações quanto à gramática do Português Brasileiro e à tradução das formas de tratamento a partir da origem geográfica dos receptores do TM e das relações sociais representadas, exemplificados no Quadro 5. Nesse trecho, constatamos que, na primeira produção, o G-I traduz literalmente o heterossemântico “apenas" ("Tu apenas o conhecias"), além de iniciar a fala da personagem Maria com o pronome oblíquo "o" e não acentuar o verbo "ir", conjugado no pretérito imperfeito. Já na Tradução Final, averiguamos que o grupo reescreve tal trecho com o heterossemântico da seguinte forma "Só conhecia ele de vista", solucionando possíveis equívocos em sua interpretação e respeitando o vernáculo do Português Brasileiro, já que, de acordo com Castilho (2014, p. 193), o pronome "ele" pode funcionar como objeto direto.

Também, na reescrita, o grupo evita a forma de tratamento "tu" e conjuga o verbo conhecer na terceira pessoa do singular no pretérito imperfeito do indicativo. Essa atitude vai em direção à adaptação da tradução das formas de tratamento à origem dos receptores do TM, já que, na cidade de São Paulo, a forma "você" com concordância canônica é de uso estendido em todas as relações sociais (SCHERRE et. al., 2015; 
NASCIMENTO, 2011) e, na primeira tradução, o grupo manteve a forma "tu" com concordância verbal canônica, assemelhando-se ao paradigma pronominal peninsular, presente no TB.

Quadro 5: Trecho comparativo entre as traduções do G-I (capacidades linguístico-discursivas)

\begin{tabular}{|l|l|}
\hline Texto & TB: "MARÍ - ¿Y tu marido y los chicos? \\
& $\begin{array}{l}\text { EMILIA. - Buenos, todos buenos. Fernando muy ocupado. Ya vendrá conmigo a saludar a tu } \\
\text { hermano politico...Tú apenas le conocias, verdad? } \\
\text { MARÍA. Le conocí cuando éramos niños. Ya sabes que su familia y la mía estaban muy unidas; } \\
\text { su padre y el mío eran socios. [...]" (BENABENTE, J. El nido ajeno, 1984) }\end{array}$ \\
\hline $\begin{array}{l}\text { Primeira } \\
\text { Tradução }\end{array}$ & $\begin{array}{l}\text { Maria: E teu marido os meninos? } \\
\text { Emilia: Bem, todos bem, Fernando está muito ocupado. Já virá comigo para saudar o teu irmão } \\
\text { político... Tu apenas o conhecias, verdade? } \\
\text { Maria: O conheci quando eramos criança. Já sabe que sua família e a minha eram muito } \\
\text { próximas; Seu pai e o meu eram sócios. [...]" }\end{array}$ \\
\hline $\begin{array}{l}\text { Tradução } \\
\text { Final }\end{array}$ & $\begin{array}{l}\text { Maria: E o pessoal? } \\
\text { Emília: Tudo bem. Fernando está na correria } \\
\text { político...Só conhecia ele de vista, verdade? } \\
\text { Maria: O conheci de criança, era todo mundo próximo; Seu pai e o meu eram sócios. [...] }\end{array}$ \\
\hline
\end{tabular}

Fonte: Autoria própria.

Assim, através da comparação entre as produções do G-I, no Quadro 5, identificamos que o uso das formas de tratamento na primeira versão manteve traços do paradigma pronominal de seu TB, tal como a concordância verbal canônica com a forma "tu", porém, na produção final, observamos maior adaptação textual do TM ao seu público meta, principalmente, no que diz respeito à origem geográfica dos receptores da tradução. Essa adaptação se refletiu na prevalência da forma "você", tanto nas interações entre amigas(os) quanto entre casais, representadas no texto. No TB em Espanhol peninsular, do séc. XIX, verifica-se o uso do "tuteo" nas interações entre as amigas "María" e "Emília". No entanto, nas interações entre "Emília" e o marido de sua amiga, ocorre o uso recíproco da forma "usted" indicando menor grau de proximidade e maior respeito, uma vez que, para Brown e Gilman (2003 [1960], p. 255), o uso recíproco da forma de poder, nesse caso o pronome "usted", não indica diferença de poder entre as personagens.

No TM final do G-I, essas diferenciações de tratamento foram unificadas com o uso do "você", levando em conta a mudança das relações sociais, pois no séc. XXI, essas relações entre amigos e familiares se dirigem para uma maior simetria (CALDERÓN CAMPOS, 2010), devido às sociedades democráticas e às ideologias igualitárias. Fato que coincide, também, com o que pontuam Brown e Gilman (2003 
[1960]), no sentido de que o desenvolvimento de sociedades abertas às ideologias igualitárias atua contra a semântica não recíproca do poder e em favor da solidariedade. Assim, na concepção dos autores, no século XIX a semântica do poder prevaleceu e garçons, soldados comuns e empregados eram chamados $\mathrm{T}$ (tratamento informal - entre iguais - relação de solidariedade), enquanto pais, patrões e irmãos mais velhos eram chamados V (tratamento formal - entre diferentes - relação de poder) . Entretanto, há evidências consistentes que indicam que no século XX a semântica da solidariedade ganhou supremacia. (BROWN; GILMAN, 2003 [1960], p. 260)

Em seu turno, ao analisar a primeira produção do G-II, enumeramos algumas dificuldades do grupo acerca da adequação do TM ao tempo e local do seu receptormeta, por exemplo, ao traduzir literalmente as expressões porto-riquenhas "hambre de javali y me comería el piano..." e "Me caso con Cristóbal", conforme expomos no quadro, a seguir:

Quadro 6: Trecho comparativo entre as traduções do G-II (capacidades de ação)

\begin{tabular}{|c|c|}
\hline $\begin{array}{l}\text { Texto- } \\
\text { base }\end{array}$ & $\begin{array}{l}\text { D. MIGUEL.--(Furioso). Pues si no es usted un caballero... ime caso con Cristóbal!...., en esta } \\
\text { sala no tienen entrada sino los caballeros. [...] } \\
\text { D. MIGUEL.--(Hecho un energúmeno). He dicho, caramba, que el señor... (A Nepa). ¿Pero tú qué } \\
\text { te crees, chiquilla? } \\
\text { SANDOVAL.--Señores... tiene razón don Miguel. Yo me voy, y no se habla más del asunto. } \\
\text { Tengo un hambre de jabali y me comería el piano..., pero ya que así lo quiere mi aciago } \\
\text { destino... Adiós, doña Rosa, Nepa. [...]". (N. CANALES, El héroi galopante, 1923) }\end{array}$ \\
\hline & $\begin{array}{l}\text { D. MIGUEL: (Furioso). Bem, se você não é um cavalheiro... Caso-me com Cristóball... E saia, } \\
\text { que neste quarto só existem entradas para cavalheiros. [...] } \\
\text { D. MIGUEL: (Feito um louco). Já disse, caramba, o senhor... (NEPA). Mas o que você pensa, } \\
\text { menina? } \\
\text { SANDOVAL: Senhores... Don Miguel está certo. Já estou indo e não se fala mais sobre esse } \\
\text { assunto. Tenho uma fome de javali e comeria um piano, se possível... mas, já que não me } \\
\text { querem por aqui... Adeus, Dona Rosa, Nepa. [...]" (1 }{ }^{a} \text { tradução do G-II, O Herói Galanteador) }\end{array}$ \\
\hline $\begin{array}{l}\text { Tradução } \\
\text { Final }\end{array}$ & 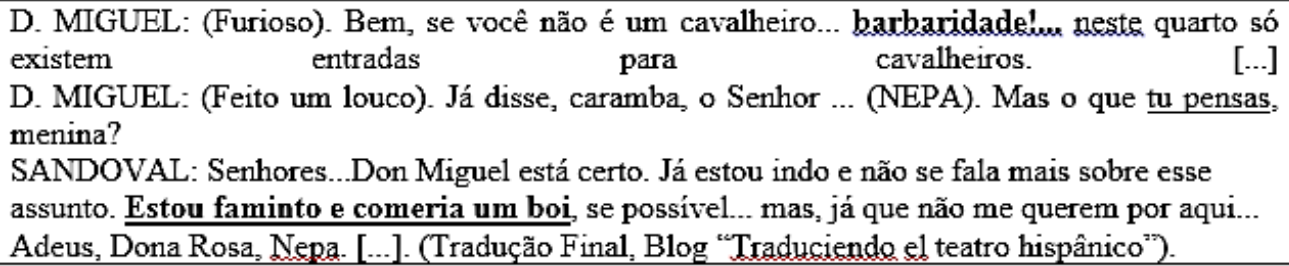 \\
\hline
\end{tabular}

Fonte: Autoria própria.

Por meio da comparação entre os trechos acima, observamos que o G-II, na tradução final, modificou as expressões destacadas, buscando relacioná-las ao tempo e ao local dos receptores-meta. O grupo traduziu a expressão "Me caso con Cristóball" do TB por "barbaridade!", muito utilizada pelos gaúchos, embora a sua tradução fosse dirigida ao público florianopolitano. Ademais, o trecho "Tengo un hambre de jabalí y 
me comería el piano" foi adaptado, na tradução final, da seguinte forma: "Estou faminto e comeria um boi". Apesar de não serem expressões características da cidade de Florianópolis, houve um intento de utilizar um léxico mais típico da Região Sul do Brasil, distante para os participantes do grupo, naturais do Estado do Ceará.

Ponderamos que, mesmo não correspondendo diretamente ao léxico da cidade de Florianópolis, o TM pode ser compreendido pelos falantes dessa cidade, pois o grupo também adaptou a maioria das formas de tratamento ao uso da região, como veremos proximamente, e, ainda, usou outras expressões que lembram a região sul brasileira, tal como a expressão "guria”. Essa atitude pode ser associada ao que Mayoral (1998) assevera sobre a tradução da variação linguística, afirmando que seria uma tradução de seus elementos marcadores, tanto os percebidos pelo receptor como norma padrão quanto os percebidos como marcados, e que o tradutor, muitas vezes, recorre a estereótipos linguísticos, por ser uma solução econômica e de fácil processamento. Embora Nord (1994) sugira que, na adequação do TM, sejam observadas as diferenças de comportamento linguístico dentro de uma entidade nacional, pois o comportamento de um determinado grupo pode ter semelhanças em um determinado campo e diferenças em outro. Dessa forma, a Sociolinguística, ao buscar descrever as "normas sociais" típicas de determinados grupos sociais (MATTOS E SILVA, 2005), pode auxiliar a atividade tradutória, assim como ocorreu com a adequação das formas de tratamento, realizada pelo grupo.

Através dos trechos anteriores, também notamos que o grupo mobilizou as características do gênero peça teatral de comédia para produzir as traduções, respeitando, por exemplo, as marcas tipográficas das rubricas por meio dos parênteses e destacando os nomes das personagens, além das sequências dialogais. Fato que adentra nas capacidades discursivas em relação ao gênero da SD. Verificamos que na Tradução Final, assim como na Primeira Tradução, o G-II respeitou a planificação e organização textual do gênero peça teatral de comédia, por exemplo, apresentando sequência textual dialogal, entre as personagens, e descritiva, nas rubricas; ausência de narrador, descrição do tempo e espaço nas rubricas, sequências dialogais escritas em prosa, sem o acompanhamento de foto ou imagens, etc. O TB desse grupo não apresentava a divisão em vários atos, assim, na tradução, o grupo respeitou essa característica. Percebemos, também, que o grupo realizou a coesão nominal e verbal do texto, por exemplo, 
utilizando-se das reiterações anafóricas pronominais, "negá-lo", "lê-lo", etc., conforme ilustramos, a seguir:

Figura 7: Trecho da Tradução Final do G-II

AMELIA: (Enojada). Com quem havia de ser? Com Nepa! Eu não sou cega. Atreva-se a
negá-lo!
SANDOVAL: Mas se eu não tenho nada...! Quero dizer, sim, nego veemente isto...
Claro! Eu... (De repente, olhando para Nepa). Nepa, minha amiga, tu que sentes , que
pensas e que falas tão bem, diga-nos algo e nos tire dessa escuridão. Diga que sim ... ou
que não ... e assim será. Já não posso mais.
NEPA: (Como quem acaba de acordar bruscamente de um sonho e em direção a eles
bem afligida). Eu? A que ponto chegamos. Nós duas como rivais! Quem poderia sequer
sonhar! Há tempos... tu lembras?, Contrastando ideais, tu sonhavas com um herói
idealizado por seu valor, e eu por sua inteligência. Agora ele veio e mudou todo o seu
conceito... e incendiou o meu. E... Nelly, querida, tem que enfrentar este conflito sem
prejudicar a nossa amizade. Não podemos evitar o que está acontecendo, mas podemos
confiar e ser sinceras e nobre uma com a outra... Um esforço! Vamos lá! Começarei eu.
Sim, Sandoval, eu te quero, sinto-me sua e o sinto meu pela lei da afinidade. (Sandoval
vai fazer um movimento, mas ela o detém com um gesto).
AMELIA: Veja, eu sabia! Pude lê-lo em seus olhos.

Fonte: Blog “Traduciendo el Teatro Hispánico”.

No que diz respeito às capacidades linguístico-discursivas, como vimos na análise diagnóstica da primeira tradução, o G-II apresentou dificuldades ao adaptar o TM à gramática, ortografia e vocabulário do Português Brasileiro, pois traduziu alguns vocábulos, sem a devida adaptação do significado ao contexto de uso, por exemplo, o verbo "callar", conjugado em Imperativo Afirmativo no TB em Espanhol, apresentouse no TM como o substantivo "Rua". Além disso, traduziu literalmente as expressões Me caso con Cristóball e hambre de javali, compreendeu o vocábulo "nena" como um nome próprio sem traduzi-la ao PB e em alguns trechos isso dificultou a compreensão, ao omitir o pronome sujeito em determinadas orações comparativas, conforme exemplificamos no quadro a seguir: 
Quadro 7: Trecho comparativo entre as traduções do G-II (capacidades

linguístico-discursivas)

\begin{tabular}{|c|c|}
\hline $\begin{array}{l}\text { Texto } \\
\text { Base }\end{array}$ & $\begin{array}{l}\text { DONA ROSA.--Miguel, ¿qué estás diciendo? No seas ridículo... } \\
\text { D. MIGUEL.-jCalle usted, señora! No me obligue a recordarle, ¡me caso con Cristóbal!, que } \\
\text { yo soy el que lleva aquí los pantalones. [...] } \\
\text { SANDOVAL-[...] ¿Cómo te lo diré? ¡Nada! Que entre un combate con toda la familia Regúlez, } \\
\text { y la amenaza de matrimonio que tú tienes suspendida sobre mi cabeza... jprefiero el combate! } \\
\text { Conque, adiós, nena... [...] } \\
\text { NEPA.--(Como despertándose bruscamente de un sueño y avanzando hacia ellos muy conmovida). } \\
\text { ¿Yo? Yo tampoco sé lo que llega. ¡Nosotras dos rivales! ¡Quién lo iba ni a soñar! Hace un rato... } \\
\text { ¿te acuerdas?, contrastando ideales, tú le soñabas héroe por el valor. yo por la inteligencia. El } \\
\text { vino, y tronchó tu ideal... y encendió el mio. Y... Nelly, hija, hay que afrontar este conflicto sin } \\
\text { lastimar ni envilecer nuestra amistad. (N.CANALES, El Héroe Galopante, 1923) }\end{array}$ \\
\hline & $\begin{array}{l}\text { DONA ROSA: Miguel, que estás dizendo? Não seja ridículo... } \\
\text { D.MIGLEL: Rua, senhora! Não me faça lembra-la. Caso-me com Cristóball, E no mais, } \\
\text { lembre-se que sou eu quem manda por aqui. [...] } \\
\text { SANDOVAL: [...] Como posso te dizer? Nada! Que entre uma luta contra toda a familia Regúlez, } \\
\text { e uma ameaça de casamento pendurada sobre a minha cabeça ... Eu prefiro o combate! Sendo assim, } \\
\text { adeus, Nena... [...] } \\
\text { NEPA: (Como quem acaba de acordar bruscamente de um sonho e em direção a eles bem afligida). } \\
\text { Eu? A que ponto chegamos. Nós duas como rivais! Quem poderia sequer sonhar! Há tempos atrás... } \\
\text { você se lembra? Contrastando ideias, rocê sonhando com um herói idealizado pelo seu valor. por } \\
\text { sua inteligência. Agora ele veio e mudou todo o seu conceito... e incendiou o meu. E... Nelly, } \\
\text { querida, tem que enfrentar este conflito sem prejudicar a nossa amizade. [...]. (1ª tradução do G-II, } \\
\text { O herói galopante). }\end{array}$ \\
\hline $\begin{array}{l}\text { Tradução } \\
\text { Final }\end{array}$ & 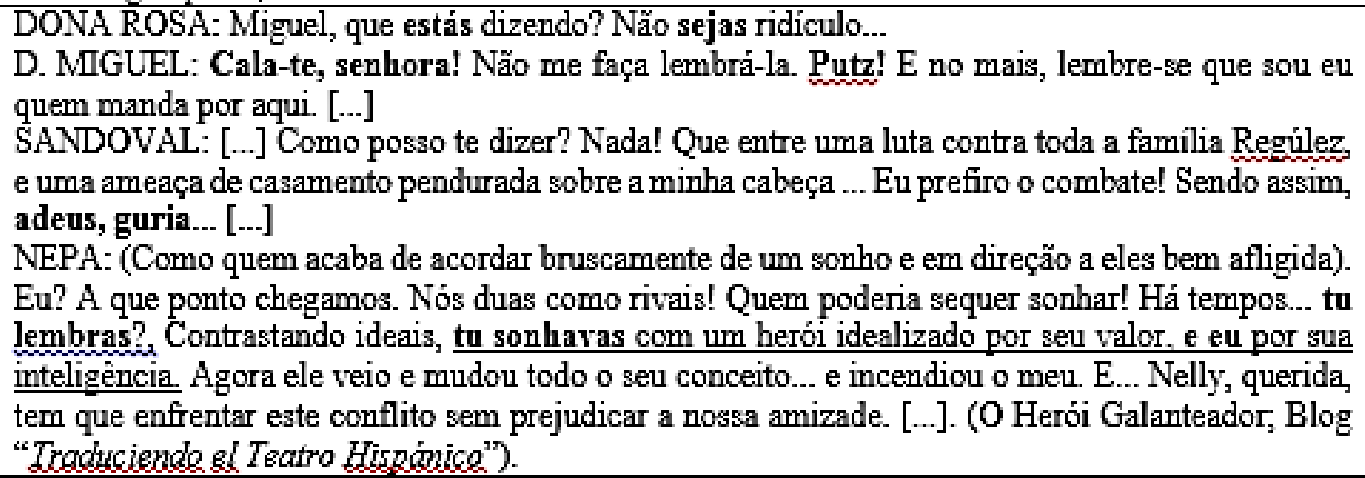 \\
\hline
\end{tabular}

Fonte: Autoria própria.

Por meio da comparação desse trechos, averiguamos que, na tradução final, o grupo buscou adaptar os trechos do TM que possuíam inadequações à gramática do PB, por exemplo, adequou a tradução do verbo em imperativo afirmativo "Calle" por "Calate", adaptando-o, inclusive, ao tratamento do interlocutor, pois, no TB, o verbo está conjugado em $3^{\mathrm{a}}$ pessoa (usted) e, no TM, o grupo conjugou esse verbo em $2^{\mathrm{a}}$ pessoa do singular (tu), talvez devido ao uso regional que esse pronome possui na Região Sul, facilmente registrado em entrevistas sociolinguísticas (SCHERRE; YACOVENCO, 2011). Também, na versão final, notamos que o grupo traduziu o vocativo "nena", presente no TB, por "guria", além de explicitar o pronome sujeito "eu", na seguinte 
oração: “[...] tu sonhavas com um herói idealizado por seu valor, e eu por sua inteligência”.

Em relação à tradução das formas de tratamento pronominais para $2^{\mathrm{a}}$ pessoa de acordo com a origem geográfica do público-meta, na primeira tradução, verificamos a predominância do pronome de tratamento "você", fato que se contrapunha ao resultado de pesquisas sociolinguísticas acerca do uso das formas de tratamento em Florianópolis. Nessa cidade, segundo Scherre et. al. (2015), o subsistema mais "tu" com concordância alta (entre $40 \%$ e $60 \%$ ) é o predominante. Dessa forma, o grupo estaria desrespeitando, em parte, o seu encargo de tradução, embora não prejudicasse a compreensão do TM, isto é, não ocasionasse um erro pragmático (NORD, 1996). No entanto, ao reescrever o TM em sua versão final, o grupo modificou o uso das formas de tratamento, correspondendo ao subsistema indicado por Scherre et.al. (2015), ou seja, no TM, o uso da forma de tratamento "tu" com concordância canônica foi predominante (10 ocorrências explícitas), embora a forma "você", com concordância canônica, também tenha computado quatro ocorrências na versão final.

Por apresentar essa alternância entre as formas "tu" e "você", na versão final, cabe examinar se o grupo também foi capaz de expressar as diferentes relações sociais (simétricas /assimétricas, formais/informais) entre as personagens por meio das formas de tratamento. Na análise diagnóstica da primeira tradução, vimos que o G-II unificou as relações de simetria e assimetria por meio da utilização da forma de tratamento "você", com concordância canônica, em todos os contextos, embora tenha preservado as ocorrências das formas "señor" e "señora", presentes no TB, traduzindo-as por "senhor" e "senhora", empregadas no tratamento da personagem Nepa dirigido a Sandoval e de D. Miguel para sua esposa, Dona Rosa.

Na versão final do TM, publicada no blog, identificamos que a forma "tu" foi usada no tratamento entre pais e filhos, entre irmãos e irmãs e a forma "você" foi utilizada pela personagem D. Miguel para tratar a Sandoval, pretendente de sua filha Amélia. Também o uso do você ocorreu duas vezes entre as irmãs Amélia e Nepa e entre esta e Sandoval. Devido ao contexto familiar, retratado no fragmento traduzido, o uso das formas "tu e você" se deu nas relações simétricas; além disso, o G-II preservou as formas "senhor e senhora" nos trechos em que se apresentaram no TB, 
principalmente, para se referir à personagem Sandoval de forma indireta, "o senhor", como uma retomada anafórica, conforme verificamos nos exemplos, a seguir:

(1) ARTURO: Sua malcriada! Aqui se faz a vontade de papai, e se ele e o senhor...

NEPA: Pois o Senhor é o nosso convidado, e eu não permito que se cometam grosserias contra ele. [...]

NEPA: Tudo bem! Sandoval, dá-me o braço. Vamos a...

D. MIGUEL: (Feito um louco). Já disse, caramba, o Senhor ... (NEPA). Mas o que tu pensas, menina? (Tradução Final - O Herói Galanteador, Blog "Traduciendo el Teatro Hispánico).

Quando se analisa uma amostra diacrônica (século anterior) e a traduz para a pós-modernidade, devem-se analisar as relações nessas sociedades e o contexto representado, para repensá-las na tradução. Dessa forma, as pistas contextuais sobre o uso das formas "o senhor" e "senhora", utilizadas no TM final, parecem indicar que não representavam uma relação assimétrica de maior poder, sendo mais bem compreendida, no caso do tratamento entre D. Miguel à sua esposa, como um trato de repreensão ou acesso de raiva e, no caso do uso da forma "senhor" para o trato a Sandoval (exemplo 1), como um intento de distanciamento entre as personagens, já que ele estava causando conflito na relação familiar, devido à disputa entre as irmãs, Nepa e Amelia. De acordo com Brown e Gilman (2003[1960]), o trato de poder ocorre quando há o tratamento não recíproco entre $\mathrm{T}-\mathrm{V}$, em que o polo de poder usa $\mathrm{T}$ e é tratado por V. Entretanto, o que observamos no TB é o contrário, D. Miguel, o patriarca da família, trata a sua mulher pela forma de poder "usted" e ela o trata por "tú". Nessa questão, a variação estilística entra em jogo, sendo necessário compreender não somente o contexto, mas o indivíduo (nesse caso, personagem) e os fatores que o estratificam socialmente, incluindo a sua relação com os demais, denominados por Souza (2011, p. 86), como fatores socioestilísticos, tais como o ambiente, a audiência, os interlocutores, etc.

Ainda sobre as capacidades linguístico-discursivas, no que se refere à capacidade de adaptar a função sintática das formas de tratamento em espanhol (sujeito, ou complemento) de acordo com a língua-meta, na primeira tradução observamos que o grupo em alguns trechos manteve o pronome explícito ou omisso. Por outro lado, na tradução final, identificamos que o grupo explicitou mais as formas de tratamento em função de pronomes sujeitos, uma tendência do PB, de acordo com Fanjul (2014, p. 30). 


\section{Conclusões}

Nossa proposta parte da interdisciplinaridade dos Estudos da Tradução, realizando uma aproximação teórica com Estudos Sociolinguísticos, Gêneros Textuais e Ensino de LE. Por meio do procedimento realizado, constatamos que a perspectiva funcionalista utilizada permitiu que os grupos de participantes, através do encargotradutório didático e da análise pré-tradutória, realizassem uma reflexão metalinguística desde a primeira tradução da SD. Também observamos que a experiência propiciou, aos grupos, conhecimento acerca do fenômeno de variação e mudança linguística no uso das formas de tratamento pronominais no par linguístico envolvido, fato refletido nas adaptações significativas entre as duas produções do TM.

Por fim, através da comparação entre a primeira e a última tradução dos grupos (avaliação formativa), concluímos que a SD a partir da tradução funcional proporcionou aos alunos: (i) o desenvolvimento de capacidades de linguagem em ambas as línguas; (ii) a compreensão da importância dos aspectos extratextuais na prática tradutória; (iii) a conscientização da impossibilidade de tradução literal entre as línguas.

\section{REFERÊNCIAS}

BARRIENTOS, B. R. R. Os quadrinhos da Maitena no ensino de Espanhol língua estrangeira: à luz da Tradução Funcionalista. 2014. 252 f. Dissertação (Mestrado em Estudos da Tradução) - Centro de Comunicação e Expressão, Universidade Federal de Santa Catarina, Florianópolis, 2014.

BARROS, E. M. D. Gestos de ensinar e de aprender gêneros textuais: a sequência didática como instrumento de mediação. 2012. 368 f. Tese (Doutorado em Estudos da Linguagem) - Centro de Letras e Ciências Humanas, Universidade Estadual de Londrina, Londrina, 2012.

BOLAÑOS-CUÉLLAR, S. Aproximación Sociolingüística a la Traducción. Forma y Función, n. 13, p.157-192, 2000.

BROWN, R.; GILMAN, A. The pronouns of power and solidarity. In: PAULSTON, C. B.; TUCKER, G. R. (eds.) Sociolinguistics. The Essencial Readings. United Kingdom: Blackwell, 2003 [1960]. p. 156-176.

CALDERÓN CAMPOS, M. Formas de tratamiento. IN: ALEZA IZQUIERDO, M.; ENGUITA UTRILLA, J. M. (coord.) La lengua española en américa: Normas y usos actuales. Universidad de Valencia, Valencia: 2010. p. 225-236. 
CASTILHO, A. T. Nova Gramática do Português Brasileiro. 1. ed., 3. reimpressão São Paulo: Contexto, 2014.

CRISTOVÃO, V. L. L. Sequências didáticas para o ensino de línguas. In: DIAS, R; CRISTOVÃO, V. L. L. O livro didático de língua estrangeira. Múltiplas perspectivas. Campinas, SP: Mercado de Letras, 2009. p. 305-344.

CRISTOVÃO, V. L. L. O gênero quarta capa no ensino de inglês. In: DIONISIO, A. et al (Org.). Gêneros textuais e ensino. São Paulo: Parábola, 2010. p. 105 - 116.

DEMÉTRIO, A. P. C. A tradução como retextualização: uma proposta para o desenvolvimento da produção textual e para a ressignificação da tradução dentro do ensino de LE. 2014. 198 f. Dissertação (Mestrado em Estudos da Tradução) - Centro de Comunicação e Expressão, Universidade Federal de Santa Catarina, Florianópolis, 2014

DOLZ, J.; SCHNEUWLY, B. Genres et progression en expression orale et écrite: éléments de réflexions à propos d'une experience romande. Enjeux, 37/38, 1996, p.4975 .

DOLZ, J.; NOVERRAZ, M; SCHENEUWLY, B. Sequências didáticas para o oral e a escrita: apresentação de um procedimento. In: ROJO, R.; CORDEIRO, G. S. Gêneros orais e escritos na escola. Campinas: Mercado de Letras, 2004. p. 95-128.

FANJUL, A. P.; Conhecendo assimetrias: a ocorrência de pronomes pessoais. In: FANJUL, A. P.; GONZÁLEZ, N. M. Espanhol e Português Brasileiro: estudos comparados. São Paulo: Parábola Editorial, 2014. p. 29-71.

FONTANELLA DE WEINBERG, M. B. Sistemas pronominales de tratamiento usados en el mundo hispánico. In: BOSQUE, I.; DEMONTE, V. (eds.): Gramática Descriptiva de la lengua española, 1. Madrid: RAE, 1999. p. 1399-1425.

KUMARAVADIVELU, B. Toward a postmethod pedagogy. TESOL Quartely, v. 35, n. 4, p. 537-60, 2001.

MARCHUSHI, L. A. Gêneros textuais: definição e funcionalidade. In: DIONISIO, A. et al (Org.). Gêneros textuais e ensino. São Paulo: Parábola, 2010. p. 19-38.

MATTOS E SILVA, R. V. Contradições no ensino de Português: A língua que se fala x A língua que se ensina. 7. ed. São Paulo, 2005. 95 p. (Repensando a Língua Portuguesa).

MAYORAL, R. La traducción de la variación lingüística. 1997. Tese (Doutorado em Estudos da Tradução) - Universidade de Granada, Granada, 1998.

MELO, N. T. Texto e contexto na construção de sentidos: a tradução em sala de aula de LE. 2012. 154 f. Dissertação (Mestrado em Estudos da Tradução) - Centro de 
Comunicação e Expressão, Universidade Federal de Santa Catarina (UFSC), Florianópolis, 2012.

NASCIMENTO, I. B. O uso variável do pronome de segunda pessoa você(s)/ cê(s) na cidade de São Paulo. 2011. 235 f. Dissertação (Mestrado em Semiótica e Linguística Geral) - Faculdade de Filosofia, Letras e Ciências Humanas, Universidade de São Paulo, 2011.

NORD, C. El error en la traducción: categorías y evaluación. In: HURTADO ALBIR, A. Estudios sobre la traducción. Castelló: Universitat Jaume I, 1996. p. 91-107.

NORD, C. Traduciendo funciones. In: HURTADO ALBIR, A. (ed.): Estudios sobre la traducción. Castelló: Publicacions de la Universitat Jaume I, 1994. p. 97-112.

NORD, C. Texto-base-texto-meta. Un modelo funcional de análisis pretraslativo. Tradução e adaptação de Christiane Nord. Castelló de la Plana: Publicacions de la Universitat Jaume I, Espanha, 2012.

PAIVA; M. C. A.; DUARTE, M. E. L. Quarenta anos depois: a herança de um programa na Sociolinguística Brasileira. In: WEINREICH, U.; LABOV, W.; HERZOG, M. Tradução de Marcos Bagno. Fundamentos empíricos para uma teoria da Mudança Linguística. São Paulo: Parábola, 2006. [1968] p. 131- 151.

REISS, K.; VERMEER, H. J. Fundamentos para una teoría funcional de la traducción. Tradução de Sandra García Reina e Celia Martín de León. Madrid: Ediciones Akal, 1996.

SCHERRE, M. M. P.; YACOVENCO, L. C. A variação linguística e o papel dos fatores sociais: o gênero do falante em foco. Revista da ABRALIN, v. eletrônico, n. especial, p. 121-146. $1^{\text {a }}$ parte 2011.

SCHERRE, M. M. P, et. al. Variação dos pronomes Tu e você. In: MARTINS, M. A; ABRAÇADO, J. (org.) Mapeamento sociolinguístico do Português Brasileiro. São Paulo: Contexto, 2015. p.133-172.

SOUZA, C. M. N. Poder e solidariedade no teatro florianopolitano dos séculos XIX e XX: uma análise sociolinguística das formas de tratamento. 2011. 280f. Dissertação (Mestrado em Linguística) - Centro de Comunicação e Expressão da Universidade Federal de Santa Catarina, Florianópolis, 2011.

STUTZ, L; CRISTÓVÃO, V. L. L. A construção de uma sequência didática na formação docente inicial de língua inglesa. Revista Signum: Estud. Ling., Londrina, n. 14/1, p. 569-589, 2011. 


\section{Como referenciar este artigo}

PONTES, Valdecy Oliveira.; PEREIRA, Livya Lea Oliveira. Tradução funcionalista e variação linguística: o uso de sequência didática no ensino de línguas. Rev.

EntreLínguas, Araraquara, v. 3, n. 2, p. 153-178, jul./dez. 2017. Disponível em: <https://doi.org/10.29051/rel.v3.n2.2017.9159>. E-ISSN: 2447-3529.

Submetido em: 18/12/2016

Solicitação de correções: 20/04/2017

Aprovado em: 24/04/2017 